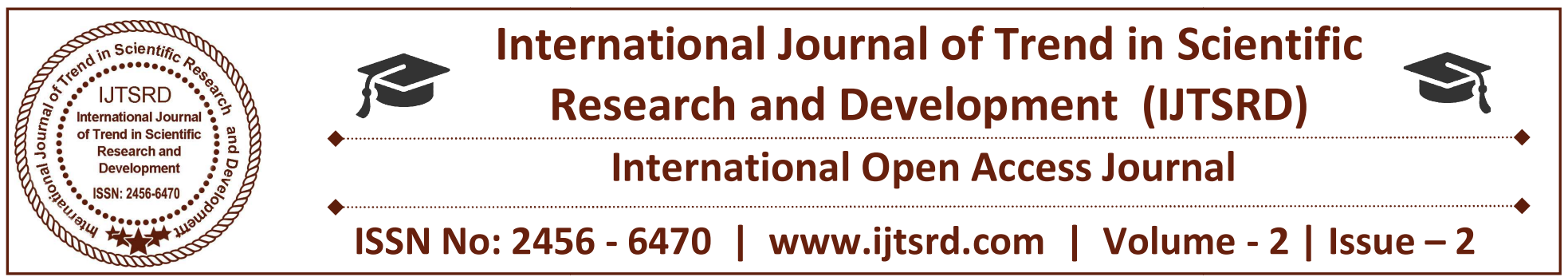

\title{
Durability Test of a Developed Radon Counter Module
}

\author{
Sung-Ha Yun \\ Department of Electrical and \\ Computer Eng., University of \\ Seoul, Seoul, Korea
}

\author{
Jai-Won Chung \\ Department of Electrical and \\ Computer Eng., University of \\ Seoul, Seoul, Korea
}

\author{
Gyu-Sik Kim \\ Department of Electrical and \\ Computer Eng., University of \\ Seoul, Seoul, Korea
}

\begin{abstract}
Radon is a natural, inert, invisible, odorless and chemically inactive radioactive gas emitted from the earth. Because inhaling radon and its radioactivedecay products causes irradiation of lung tissue, prolonged exposure to a high concentration of radon significantly increases the risk of developing cancer. For our experiments, we implemented a radon counter with a PIN photodiode radon-sensor module. The radon counter was equipped with a $\mathrm{Wi}$-Fi module for wireless communication and radon monitoring. In order to improve the performance of the developed radon counter module, the durability test was performed.
\end{abstract}

Keywords: radon, high concentration, PIN photodiode, Wi-Fi, durability test

\section{Introduction}

Radon is a chemical element with symbol $\mathrm{Rn}$ and atomic number 86. It is a radioactive, colorless, odorless, tasteless noble gas. It occurs naturally as an intermediate step in the normal radioactive decay chains through which thorium and uranium slowly decay into lead; radon, itself, is a decay product of radium. Its most stable isotope, ${ }^{222} \mathrm{Rn}$, has a half-life of 3.8 days. Since thorium and uranium are two of the most common radioactive elements on Earth, and since their isotopes have very long half-lives, on the order of billions of years, radon will be present long into the future. Unlike all the other intermediate elements in the decay chains, radon is, under normal conditions, gaseous and easily inhaled. Radon gas is a health hazard.
There are many commercial instruments and techniques available for measuring radon indoors. Most detectors for evaluating indoor radon levels are passive in that they do not require external power. The principal drawback of passive detectors is that they only measure radon concentration at one specific location for a specific period. Because many variables influence radon concentration levels, a single estimate of radon concentration is likely to have a significant error. In [1], highly sensitive, electrostatic collection chambers using Columbia Resin 39 (CR-39) plastic track detectors were developed for measuring lowlevel radon. In [2], the unique characteristics and the shortcomings of track detectors for neutron and radon dosimetry is described and compared with those of alternative detector systems. In [3], low-cost alphaparticle sensor systems using special Positive MetalOxide Semiconductor (PMOS) transistors in a floating n-well were developed for radon and radon-daughter monitoring and dosimetry. In [4], a radon detector employed an electrically charged, pressed, porous metal filter that permitted radon-gas diffusion while blocking ambient light. It readily trapped both attached and unattached Polonium-214 (Po-214) and Polonium 218 (Po-218) ions present in gas passing through the filter. The filter was positively charged relative to the unbiased PN junction of a photo-diode detector within a detection chamber. In [5], an alpha particle detector was designed using a commercial silicon photodiode. An application of a silicon photodiode detector for radon progeny measurements is presented in [6]. 
In this paper, we describe a low-end real time radon detector that uses a PIN photodiode radon-sensor with a Wi-Fi wireless communication module. The performance of the developed radon counter module could be improved through a variety of durability tests.

\section{Pin Photodiode Radon Counter}

A commercial PIN photodiode can be used to detect radiation, and particularly, alpha particles. It is low cost, has good quantum efficiency, and good energy resolution. It can also work with a low bias voltage. A PIN photodiode is more widely used than a conventional photomultiplier tube (PMT) because it requires less biasing to operate and it is very compact. The Mega 2560 is a microcontroller board based on the Atmega 2560. It has 54 digital input/output pins (of which 15 can be used as Pulse Width Modulation (PWM) outputs), 16 analog inputs, 4 UARTs (hardware serial ports), a $16 \mathrm{MHz}$ crystal oscillator, a USB port, a power jack, an in-circuit serial programming (ICSP) header, and a reset button. It contains everything needed to / support the microcontroller; it just needs to be connected to a computer with a USB cable or powered with an ACto-DC adapter or battery. The Mega 2560 board is compatible with most shields designed for the Uno and the older Duemilanove and Diecimila boards.

In our experiments, we used a radon counter assembled from very low-cost consumer electronics. The circuit designs for the power, high voltage generator, LCD, switch, LED, buzzer, microprocessor control unit (MCU), and sensor circuit were made. Using these circuit elements, we developed the PIN photodiode radon-counter printed circuit board (PCB) layout and then assembled the PIN photodiode radon counter shown in Fig. 1.

The ESP8266 Wi-Fi module is a self-contained system-on-chip (SOC) with integrated TCP/IP protocol stacks that can give any microcontroller access to a Wi-Fi network. The ESP8266 is capable of either hosting an application or offloading all Wi-Fi networking functions to another application processor. Each ESP8266 module comes pre-programmed with AT Command Set firmware, meaning the module can be hooked up to an Arduino device with about the same Wi-Fi ability as a Wi-Fi shield. The ESP8266 module is an extremely cost-effective board with a huge, and ever growing, community of users. This module has powerful enough on-board processing and storage capability to allow it to be integrated with the sensors and other application-specific devices through its general-purpose input/outputs (GPIOs), with minimal development up-front and minimal loading during runtime. Its high degree of on-chip integration allows for minimal external circuitry. The PIN photodiode radon counter with the ESP8266 Wi-Fi module is shown in Fig. 2.

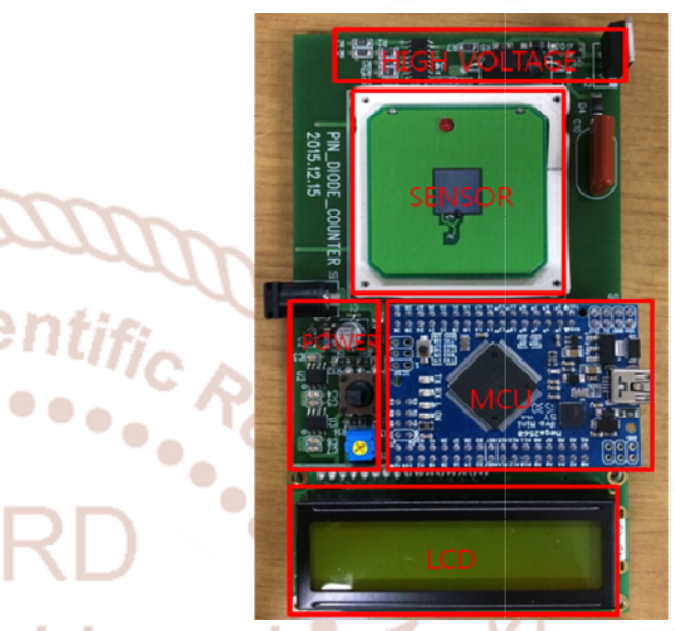

Fig. 1 Implemented PIN photodiode radon counter

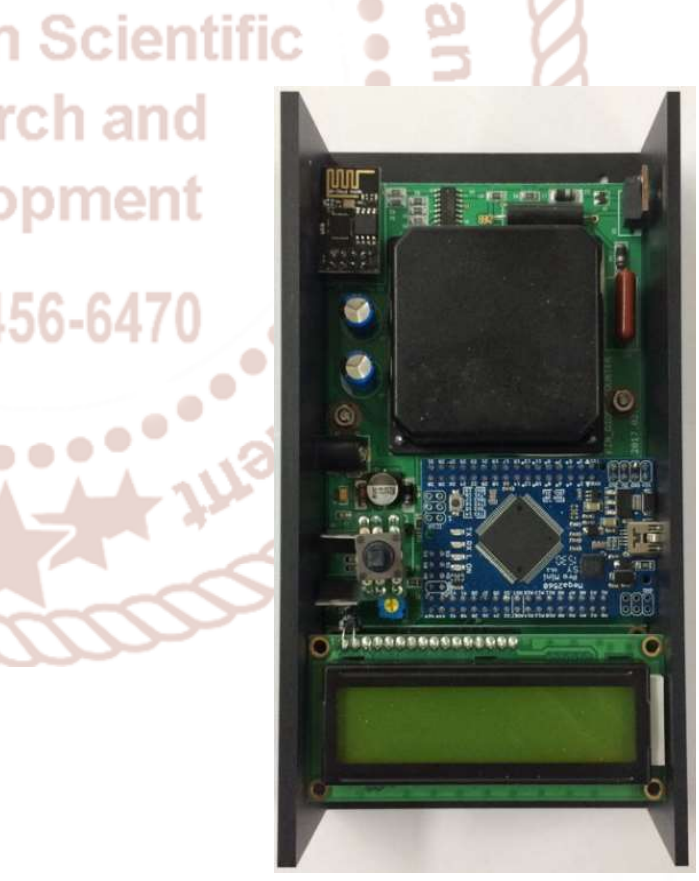

Fig. 2 Pin photodiode radon counter with Wi-Fi 
International Journal of Trend in Scientific Research and Development (IJTSRD) ISSN: 2456-6470

Table 1. Testing method and evaluation criteria for the durability test

\begin{tabular}{|c|c|c|c|}
\hline \multicolumn{2}{|c|}{ Test item } & Testing method & \multirow{7}{*}{$\begin{array}{l}\text { Evaluation criteria } \\
\text { No abnormality in the } \\
\text { appearance, the LCD } \\
\text { display, and the } \\
\text { operation of the radon } \\
\text { counter }\end{array}$} \\
\hline \multirow[t]{6}{*}{$\begin{array}{l}\text { Environmental } \\
\text { test }\end{array}$} & $\begin{array}{l}\text { Heat } \\
\text { resistance }\end{array}$ & $\begin{array}{l}\text { Temperature of } 80^{\circ} \mathrm{C} \text { for } 24 \text { hours (power } \\
\text { off) }\end{array}$ & \\
\hline & $\begin{array}{l}\text { Cold } \\
\text { resistance }\end{array}$ & $\begin{array}{l}\text { Temperature of }-30^{\circ} \mathrm{C} \text { for } 24 \text { hours } \\
\text { (power on) }\end{array}$ & \\
\hline & $\begin{array}{l}\text { Humidity } \\
\text { resistance }\end{array}$ & $\begin{array}{l}\text { Relative humidity of } 95 \% \text { and temperature } \\
\text { of } 40^{\circ} \mathrm{C} \text { for } 24 \text { hours (power on) }\end{array}$ & \\
\hline & $\begin{array}{l}\text { Temperature } \\
\text { cycle }\end{array}$ & $\begin{array}{l}\text { Temperature of }-20{ }^{\circ} \mathrm{C} \text { for } 1 \text { hour and } \\
\text { temperature of } 70{ }^{\circ} \mathrm{C} \text { for } 1 \text { hour, } \\
\text { continuously (power on) } \\
\text { Repeat } 5 \text { times }\end{array}$ & \\
\hline & $\begin{array}{l}\text { Thermal } \\
\text { shock }\end{array}$ & $\begin{array}{l}\text { Temperature of }-40{ }^{\circ} \mathrm{C} \text { for } 30 \text { minutes and } \\
\text { temperature of } 80{ }^{\circ} \mathrm{C} \text { for } 30 \text { minutes, } \\
\text { continuously (power off) } \\
\text { Repeat } 50 \text { times }\end{array}$ & \\
\hline & $\begin{array}{l}\text { Vibration } \\
\text { withstand }\end{array}$ & $\begin{array}{l}\text { Vibration frequencies of } 10 \mathrm{~Hz} \text { and } 50 \mathrm{~Hz} \\
\text { changed minutely with an oscillation } \\
\text { amplitude of } 1.5 \mathrm{~mm} \text { for } 2 \text { hours in the } \mathrm{X}, \mathrm{Y} \text {, } \\
\text { and } \mathrm{Z} \text { axis directions, respectively (power } \\
\text { off) }\end{array}$ & \\
\hline $\begin{array}{l}\text { Marginal } \\
\text { test }\end{array}$ & HALT & $\begin{array}{l}\text { Testing of operating limits for lower and } \\
\text { upper temperatures and vibration } \\
\text { Repeat the test increased test conditions at } 5 \\
\text { minute intervals until the alteration is } \\
\text { detected }\end{array}$ & $\begin{array}{l}\text { Measurement of the } \\
\text { operating limits for } \\
\text { lower and upper } \\
\text { temperatures and } \\
\text { vibration }\end{array}$ \\
\hline
\end{tabular}

Humidity resistance, a temperature cycle, a thermal shock, a vibration withstand, and a highly accelerated life test (HALT). Table 1 shows testing method and evaluation criteria for the durability test. For the heat resistance test, the radon counter which was not powered was evaluated at temperature of $80^{\circ} \mathrm{C}$ for 24 hours. The cold resistance test was performed by evaluating the radon counter powered with an AC-to$\mathrm{DC}$ adapter at temperature of $-30{ }^{\circ} \mathrm{C}$ for 24 hours. The humidity resistance test were performed by evaluating the radon counter powered with the adapter at relative humidity of $95 \%$ and temperature of $40{ }^{\circ} \mathrm{C}$ for 24 hours. The temperature cycle test and the thermal shock test were performed to evaluate the ability of the radon counter to resist extremely low and extremely high temperatures, as well as the ability of the radon counter to withstand cyclical exposures to these temperature extremes. For temperature cycle test, the radon counter powered with the adapter was evaluated at temperature of $-20{ }^{\circ} \mathrm{C}$ for 1 hour, and then evaluated at temperature of $70{ }^{\circ} \mathrm{C}$ for 1 hour, continuously. This process was repeated total 5 times. For the thermal shock test, the radon counter which was not powered was evaluated at temperature of -40 ${ }^{\circ} \mathrm{C}$ for 30 minutes, and then evaluated at temperature of $80{ }^{\circ} \mathrm{C}$ for 30 minutes, continuously. This process was repeated total 50 times. The vibration withstand test was performed by evaluating the radon counter which was not powered was evaluated at two vibration frequencies with an oscillation amplitude of $1.5 \mathrm{~mm}$. Vibration frequencies were $10 \mathrm{~Hz}$ and $50 \mathrm{~Hz}$, which were changed minutely. This process was performed for 2 hours in the $\mathrm{X}, \mathrm{Y}$, and $\mathrm{Z}$ axis directions, respectively. HALT is a test technique called test-to-fail, where a product is tested until failure. HALT was performed to evaluate operating limits of the radon counter for lower and upper temperatures, and vibration. If any alteration was not detected at an initial temperatures and vibration for 5 minutes, the test was repeated at increased test conditions until the alteration was detected. In the environmental tests, which were the heat resistance, the cold resistance, the humidity resistance, the temperature cycle, the thermal shock, and the vibration withstand test, the evaluation criteria was that there was no abnormality in the appearance, the 
LCD display, and the operation of the radon counter. temperatures and vibration were measured and The evaluation criteria for HALT were that operating evaluated.

limits of the radon counter for lower and upper

Table 2. Testing environment and result for the durability test

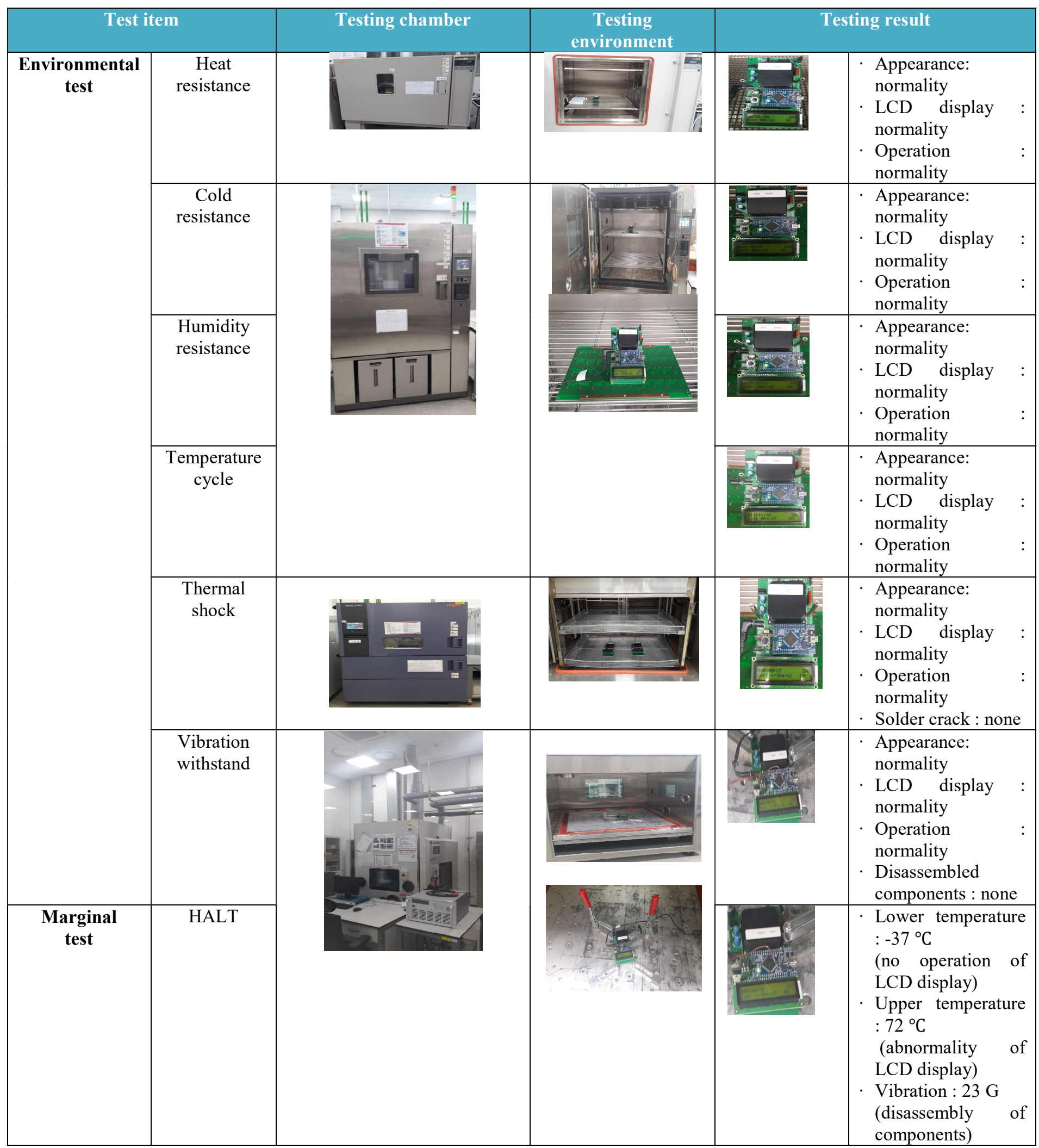


Table 2 shows the testing environment and result for the durability test. For the heat resistance test, we used a high-temperature chamber (Espec, Tokyo, Japan), which could change the temperature from room temperature to $200{ }^{\circ} \mathrm{C}$. A thermo-hygrostat chamber (Espec), which could change the temperature from $-40{ }^{\circ} \mathrm{C}$ to $200{ }^{\circ} \mathrm{C}$ and the relative humidity from $20 \%$ to $98 \%$, was used for the cold resistance, the humidity resistance, and the temperature cycle test. For the thermal shock test, a thermal shock chamber (Espec), which could change the temperature from -77 ${ }^{\circ} \mathrm{C}$ to $205{ }^{\circ} \mathrm{C}$, was used. For the vibration withstand test and the HALT, we used a HALT chamber (Qualmark, Denver, USA), which could change the temperature from $-100{ }^{\circ} \mathrm{C}$ to $200{ }^{\circ} \mathrm{C}$ within 2 minutes and the vibration from $1 \mathrm{G}$ to $50 \mathrm{G}$.

Any abnormalities were not observed on the appearance, the LCD display, and the operation of the radon counter in the environmental tests, which were the heat resistance, the cold resistance, the humidity resistance, the temperature cycle, the thermal shock, and the vibration withstand test (Table 2). In the HALT, we observed operating limits of the radon counter, which were the temperatures from $-37^{\circ} \mathrm{C}$ to $72{ }^{\circ} \mathrm{C}$ and the vibration of $23 \mathrm{G}$. The LCD display was not operated at the temperature of $-37{ }^{\circ} \mathrm{C}$, and abnormality of LCD display screen was observed at the temperature of $72{ }^{\circ} \mathrm{C}$. The high voltage chamber of the radon counter was disassembled at the vibration of $23 \mathrm{G}$.

\section{Concluding Remarks}

Radon is an invisible, odorless and chemically inactive radioactive gas that is produced by the decay of uranium ore, such as radium, actinium, or thorium. Because inhaling radon and its radioactive decay products causes irradiation of lung tissue, prolonged exposure to high concentrations of radon significantly increases the risk of developing cancer. It has been reported that the US. Environmental Protection Agency estimates exposure to naturally occurring radon leads to 21,000 lung cancer deaths nationwide each year, making radon the nation's primary environmental health threat and second only to cigarette smoking as a cause of fatal lung cancer. Various types of equipment and components have been proposed to date for radon detection. For our experiments, we implemented a radon counter with a PIN photodiode radon-sensor module. The radon counter was equipped with a WiFi module for wireless communication and radon monitoring. We confirmed that the performance of the developed radon counter module was improved through some durability test.

\section{Acknowledgment}

This work was also supported by the National Research Foundation of Korea (NRF) grant funded by the Korea government (MSIP) (No. 2016011249).

\section{References}

1. Hiroshi Miyake, Keiji Oda and Masami Michijima, "Portable and high-sensitive apparatus for measurement of environmental radon using CR-39 track detector," Japanese Journal of Applied Physics, Vol.26, No.4, pp.607-610, April, 1987

2. L. Tommasino, "Importance of track detectors in radiation dosimetry," Nucl. Tracks Radiat. Meas., Vol.22, No.1-4, pp.707-717, 1993

3. T. Streil, R. Klinke, W. Birkholz, and G. Just, "New alpha radiation detection systems for radon and radon daughter monitoring," Radiation Measurements, Vol.25, No.1-4, pp.621-622, 1995

4. Peter J. Diamondis, "Radon gas measurement apparatus having alpha particle-detecting photovoltaic photodiode surrounded by porous pressed metal daughter filer electrically charged as PO-219 ion accelerator," US patent, P.N. 5489780, Feb. 1996

5. A. Chambaudet, D. Klein, and M. Voytchev, "Study of the response of silicon detector for alpha particles," Radiation Measurements, Vol.28, No.1-6, pp.127-132, 1997

6. M. Voytchev, D. Klein, A. Chambaudet, G. Georgiev, and M. Iovtchev, "Applications of a silicon photodiode detector for radon progeny measurements," Radiation Measurements, Vol.31, pp.375-378, 1999 